\title{
Assessment of Zinc and Nickel Profile of Vegetables Grown in Soil Irrigated with Sewage Water
}

\author{
HAO LIANG1, ZAFAR IQBAL KHAN ${ }^{2 *}$, KAFEEL AHMAD ${ }^{2}$, ANAM NISAR ${ }^{2}$, \\ QAISAR MAHMOOD ${ }^{3}$, ABDOL GHAFFAR EBADI ${ }^{4}$, MOHSEN TOUGHANI ${ }^{5}$ \\ ${ }^{1}$ Beijing Vegetable Research Center, Beijing Academy of Agriculture and Forestry Sciences, Beijing 100097, China \\ ${ }^{2}$ Department of Botany, University of Sargodha, Sargodha, Pakistan \\ ${ }^{3}$ Department of Environmental Sciences, COMSATS University Islamabad, Abbottabad, Pakistan \\ ${ }^{4}$ Department of Agriculture, Jouybar Branch, Islamic Azad University, Jouybar, Iran \\ ${ }^{5}$ Department of Fishery, Islamic Azad University Babol Branch, Babol, Iran
}

\begin{abstract}
The current investigation assessed the nickel and zinc contents of the soil, and the vegetables grown in wastewater irrigated areas. Atomic Absorption Spectrophotometer (AA-6300 Shimadzu Japan) assessed the metal profile of the samples. The mean concentrations of metals in soil samples varied from 0.085 to $1.611 \mathrm{mg} / \mathrm{kg}$ for $\mathrm{Ni}$ and $0.453 \sim 0.908 \mathrm{mg} / \mathrm{kg}$ for $\mathrm{Zn}$. In vegetables, the maximum Ni concentration was observed in Capsicum baccatum consequent to wastewater irrigation, while its minimum concentrations were noticed in Capsicum frutescens after canal water irrigation. Sewage water irrigation resulted in the highest Zn contents in Solanum lycopersicum and the lowest $\mathrm{Zn}$ contents were noticed in Capsicum baccatum after canal water irrigation. The daily intake values of $\mathrm{Ni}$ and $\mathrm{Zn}$ were higher caused by sewage water irrigation as compared to the canal water irrigation in all tested vegetable samples. Health risk index (HRI) values for Ni and Zn accumulation in vegetables fell within the permissible limit in Pakistan and these were regarded as appropriate for human intake.
\end{abstract}

Keywords: Trace metal, sewage water, health risk, Pollution load index

\section{Introduction}

Metals have been categorized as essential and non-essential based on their metabolism in biological systems [1-5]. The higher quantities of essential heavy metals may be highly poisonous [6,7]. These elements have a great impact on many metabolic pathways of living organisms [8-13]. Living organisms may store heavy metals upon their entry in the body in various forms which can be categorized into three forms namely extracellular accumulation, cell surface binding and intracellular accumulation. The binding over cell surface could be by inactive or active microorganisms as it is independent of metabolism. The intracellular and extracellular accumulation of metals occurs in the living cells occurs by active transport. Even trace quantities of some heavy metals in organisms prove to be harmful since they interfere with the metabolic functions of the cells [14-18].

The ecosystem and environment are affected unfavourably by the soil degradation caused by heavy metal contaminants throughout the world [19-21]. Many health problems occur owing to the intense metal concentrations in soil which are absorbed by the growing plants resulting in food chain contamination [22-24]. Owing to industrial manufacturing, municipal solid wastes, industrial effluents, mining and smelting, pesticides, fertilizers and wastewater irrigation in agriculture, the soil is polluted with heavy metals and soil contamination has radically enhanced in recent past [25- 29]. The vegetative tissues of the crop plants get maximum heavy metals from the contaminated rhizosphere and pose high health risk to humans [30-33]. If the wastewater irrigation of crops continues for a longer duration, it will result in the food web contamination [34- 37].

$\overline{\text { *email: khan.zi126@yahoo.com,zafar.khan@uos.edu.pk }}$ 
Wastewater from industrial and drug production activities have higher concentrations of heavy metals [38-40]. Metals accumulation in vegetables could be attributed to the excessive use of wastewater in agricultural activities [12,13,41]. Al-Jassir et al., [42] demonstrated the toxic limits of heavy metals in food items. Prolonged use of large quantities of these elements in the form of contaminated vegetables consumption can lead to many disorders in humans and other organisms and may prove lethal if exceeds the safe limits [43-49].

Keeping in view of the published literature, aim of the current investigation was to determine the $\mathrm{Ni}$ and $\mathrm{Zn}$ concentrations in soil samples watered with fresh (canal) and waste (sewage) water; to determine these metals accumulations in vegetables grown in these soils, and to evaluate the health risk caused by the consumption of contaminated vegetables by human.

\section{Materials and methods}

\subsection{Study area}

Current investigation was carried out in Sargodha City, Punjab, Pakistan $\left(32.0740^{\circ} \mathrm{N}, 72.6861^{\circ} \mathrm{E}\right)$ (Figure 1). The areas watered with sewage wastewater and canal water in the Sargodha city. Most of the agricultural areas of the city are saline soils. The vicinity of the city is mostly irrigated with industrial wastewater. Two sites were selected for the current research work based upon the irrigation practice i.e. site 1 , irrigated by canal water (CWI) and site 2 , where irrigated by industrial sewage water (SWI).

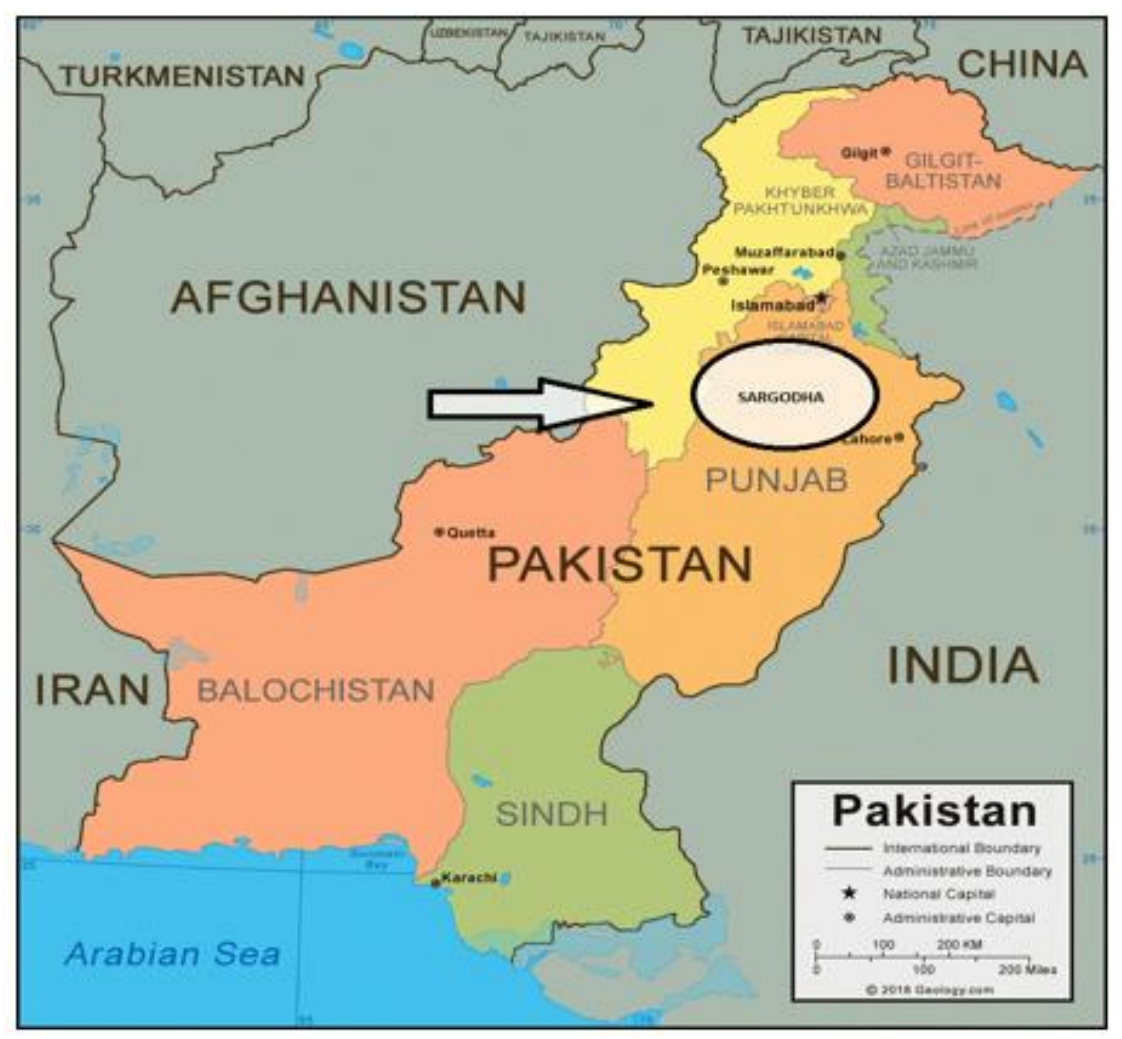

Figure 1: Location map of the study site

\subsection{Sample preparation}

In present research, Brassica rapa L. (roots), Capsicum frutescens L. (fruit), Capsicum baccatum L. (fruit), Capsicum annuum L. (fruit), Curcuma longa L. (rhizome), Raphanus sativus L. (roots), Solanum lycopersicum L. (fruit) and Zingiber officinale Roscoe (roots) were chosen as vegetables samples. The vegetable samples were collected at maturity. 


\subsection{Wet digestion process}

Double acid digestion was accomplished before the analyses of samples for metals accumulation. Soil and plant samples were soaked in concentrated acid overnight, then digested with $\mathrm{H}_{2} \mathrm{O}_{2}$ using hot plate. The volume of digested samples were made upto $50 \mathrm{ml}$ using distilled water. Diluted samples were filtered and stored for further analyses [50].

\subsection{Nickel and Zinc analysis}

Atomic absorption spectrophotometer (AAS-6300 Shimadzu Japan) performed analysis of samples for $\mathrm{Ni}$ and $\mathrm{Zn}$.

\subsection{Statistical Analysis}

The statistical significance of variations among different samples was analysed using SPSS (Statistica1 Package for Social Sciences). One-way ANOVA (Analysis of Variance) determined the statistical significance of different concentrations.

\subsection{Daily intake of metals (DIM)}

DIM is the amount calculated to the intake of trace metals orally. It is calculated as:[51].

$$
D I M=\frac{\text { Concentrations of metal } x \text { Daily consumption of vegetable }(\mathrm{kg} \text { per person) }}{\text { Average body weight of a person }}
$$

\subsection{Pollution load index (PLI)}

The concentration of metals in soil was evaluated by PLI. It was determined by the formula:

$$
P L I=\frac{\text { metal concentrations in soils }}{\text { metal concentration taken as reference }}
$$

\subsection{Health risk index}

Health risk index (HRI) was determined relative to DIM value and oral reference dose (RfD) according to following expression: [52].

$$
H R I=\frac{D I M}{\text { Oral reference dose }}
$$

\subsection{Bio concentration factor}

Metal concentration accumulated in the body of living being is called bioconcentration factor (BCF) [53]. It was computed using the given formula:

$$
H R I=\frac{\text { Vegetable metals }}{\text { Soil metals }}
$$

\section{Results and discussions}

\subsection{Nickel and Zinc contents of sampled soils}

The mean Ni concentration in soil differed from 0.805 to $1.611 \mathrm{mg} / \mathrm{kg}$. Highest concentration of Ni in soil was detected during SWI and the lowest concentration was observed for CWI. The ANOVA results exhibited the variations to be non-significant $(p>0.05)$ in $\mathrm{Ni}$ concentration with respect to the irrigated sites (Table 1). The mean $\mathrm{Zn}$ concentration in soil varied from $0.453-0.908 \mathrm{mg} / \mathrm{kg}$. The maximum $\mathrm{Zn}$ values were present in the soil irrigated with sewage water while the minimum values were observed by canal water irrigation. The AN0VA results depicted significant $(p \leq 0.05)$ impact of irrigation source on $\mathrm{Zn}$ concentration (Table 1). 
Table 1. Analysis of variance and mean values of nickel and zinc $(\mathrm{mg} / \mathrm{kg})$ in soil and vegetables treated with canal and sewage water

\begin{tabular}{|c|c|c|c|c|c|c|}
\hline \multirow{3}{*}{ Vegetables } & \multicolumn{3}{|c|}{ Nickel } & \multicolumn{3}{|c|}{ Zinc } \\
\hline & \multicolumn{2}{|c|}{ Mean \pm S.E. } & \multirow{2}{*}{$\begin{array}{c}\text { Mean } \\
\text { Square }\end{array}$} & \multicolumn{2}{|c|}{ Mean \pm S.E. } & \multirow[t]{2}{*}{$\begin{array}{c}\text { Mean } \\
\text { Square }\end{array}$} \\
\hline & CWI & SWI & & CWI & SWI & \\
\hline Soil & $0.805 \pm 0.175$ & $1.611 \pm 0.350$ & $4.249^{\mathrm{ns}}$ & $0.453 \pm 0.061$ & $0.908 \pm 0.123$ & $11.039^{*}$ \\
\hline R. sativus & $0.461 \pm 0.020$ & $0.919 \pm 0.039$ & $110.4^{* * * *}$ & $4.000 \pm 0.570$ & $7.999 \pm 1.139$ & $9.853^{*}$ \\
\hline B. rapa & $0.450 \pm 0.006$ & $0.899 \pm 0.013$ & $999.0^{* * *}$ & $4.324 \pm 0.933$ & $8.645 \pm 1.867$ & $4.284^{\mathrm{ns}}$ \\
\hline Z. officinale & $0.466 \pm 0.022$ & $0.934 \pm 0.041$ & $101.5^{* * *}$ & $1.905 \pm 1.142$ & $4.763 \pm 2.308$ & $1.232^{\mathrm{ns}}$ \\
\hline C. baccatum & $0.513 \pm 0.032$ & $1.023 \pm 0.063$ & $51.76^{* * *}$ & $7.479 \pm 0.521$ & $14.954 \pm 1.043$ & $1.232^{\mathrm{ns}}$ \\
\hline C. frutescens & $0.324 \pm 0.042$ & $0.646 \pm 0.085$ & $11.55^{*}$ & $1.936 \pm 0.494$ & $3.870 \pm 0.989$ & $41.142^{* * *}$ \\
\hline C. аппиит & $0.444 \pm 0.023$ & $0.886 \pm 0.046$ & $73.00^{* * *}$ & $4.688 \pm 0.676$ & $9.360 \pm 1.351$ & $11.552^{*}$ \\
\hline S. lycopersicum & $0.394 \pm 0.023$ & $0.786 \pm 0.046$ & $57.43^{* * *}$ & $3.791 \pm 1.215$ & $1.036 \pm 1.351$ & $13.074^{*}$ \\
\hline C. longa & $0.436 \pm 0.020$ & $0.869 \pm 0.039$ & * $\quad 98.721^{* *}$ & $3.668 \pm 0.898$ & $8.499 \pm 1.139$ & $11.094^{*}$ \\
\hline
\end{tabular}

$*, * *, * * *=$ significant at $\mathrm{O} . \mathrm{O} 5, \mathrm{O} . \mathrm{O} 1$ and $\mathrm{O} .0 \mathrm{O} 1$ levels, $\mathrm{ns}=$ non-significant.

Soil acts as the pivotal part of agricultural system and the metals and mineral reserves in soil govern the amassing of heavy metal in producers. Levels of heavy metals in soil samples detected during the current study were lesser when compared to the safe allowed limit of $\mathrm{Ni}(50 \mathrm{mg} / \mathrm{kg})$ and $\mathrm{Zn}(200$ $\mathrm{mg} / \mathrm{kg}$ ) as advised by Rowell et al. [54]. This might be due to soil factors like $\mathrm{pH}$, concentration of humus, oxidation and reduction potential and rate of addition of metals into the soil which in turn control the capacity of soil to hold them.

\subsection{Nickel and Zinc concentrations in vegetable samples}

In vegetable samples, the mean $\mathrm{Ni}$ contents $(\mathrm{mg} / \mathrm{kg}$ ) fluctuated from 0.461 to 0.919 (Raphanus sativus), 0.450 to 0.899 (Brassica rapa), 0.466 to 0.934 (Zingiber officinale), 0.513 to 0.023 (Capsicum baccatum), 0.324 to 0.646 (C. frutescens), 0.444 to 0.886 (Capsicum annuum), 0.394 to 0.786 (Solanum lycopersicum) and 0.436 to 0.869 (Curcuma longa) (Table 1, Figure 2). The highest $\mathrm{Ni}$ concentration was present in $C$. baccatum under SWI and the lowest Ni contents were noticed in $C$. frutescens under CWI. Analysis of variance (ANOVA) exhibited the significant effects $(\mathrm{p} \leq 0.05)$ of water quality on the $\mathrm{Ni}$ contents of various vegetables ( $R$. sativus, $C$. annuum, S. lycopersicum, $Z$. officinale, C. frutescens, B. rapa, C. longa and C. baccatum) (Table 1, Figure 2). 


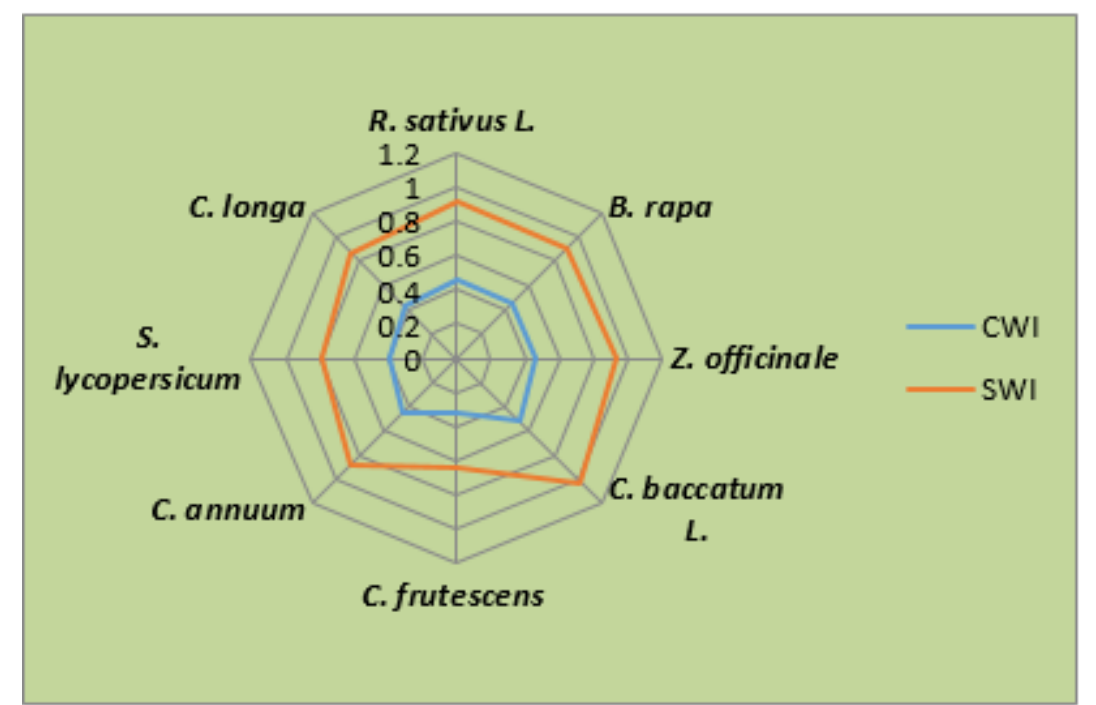

Figure 2. Fluctuations in Ni concentrations in different vegetables irrigated with canal and sewage water

The Ni concentrations in the investigated plant samples were lower than its safe limit of $2 \mathrm{mg} / \mathrm{kg}$ disclosed by Chiroma et al. [55]. Orisakwe et al., [56] observed the Ni concentration of $0.66 \mathrm{mg} / \mathrm{kg}$ in fluted pumpkin (T. occidentalis), which might be due to differences in geographical location or soil characteristics. The absorption of $\mathrm{Ni}$ depends upon its compound chemical form, the water-soluble forms (chloride, nitrate, sulphate) being more easily absorbed [57,58]. The extended exposure to heavy metals like $\mathrm{Ni}, \mathrm{Zn}, \mathrm{Cu}$ and As can lead to injurious health complexities in humans [59]. The Ni contents can be easily extracted from soil and the plants anchored in it [60-65].

In the assessed vegetable samples, the mean $\mathrm{Zn}$ concentrations $(\mathrm{mg} / \mathrm{kg})$ was observed between 4.07.999 (R. sativus), 4.324-8.645 (B. rapa), 1.905-4.763 (Z. officinale), 7.479-14.954 (C. baccatum), 1.936-3.870 (C. frutescens), 4.688-9.360 (C. annuum), 3.791-1.036 (S. lycopersicum) and 3.668-8.499 (C. longa) (Table 1, Figure 3). The maximum $\mathrm{Zn}$ values were present in S. lycopersicum irrigated by wastewater and the minimum $\mathrm{Zn}$ values were present in $C$. baccatum irrigated by canal water. ANOVA depicts significant effects of irrigation water $(\mathrm{p} \leq 0.05)$ on $\mathrm{Zn}$ concentration in C. frutescens, $C$. annuum, $C$. longa, $R$. sativus, and S. lycopersicum, whereas non-significant effect ( $\mathrm{p}>0.05)$ was depicted in B. rapa, C. baccatum and Z. officinale, (Table 1, Figure 3).

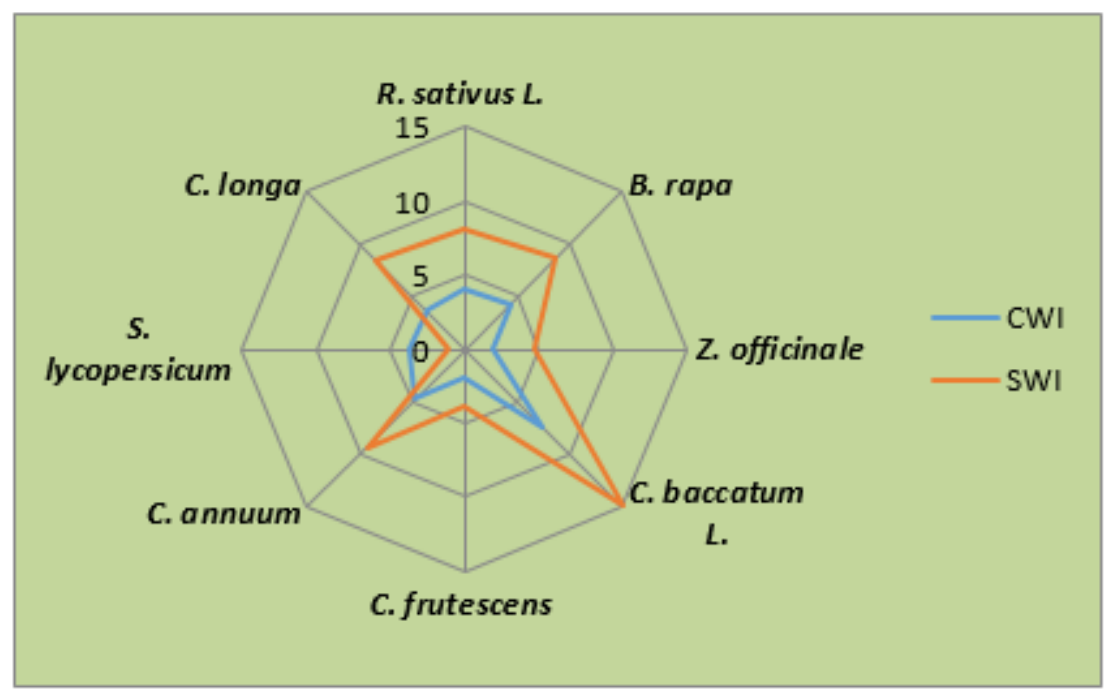

Figure 3. Fluctuations in zinc concentrations in different vegetables treated with canal and sewage water 
The $\mathrm{Zn}$ content of vegetables was lower than the safe limit of $\mathrm{Zn}(50 \mathrm{mg} / \mathrm{kg})$ as suggested by Chiroma et al. [55]. The current research explored a relative enhancement of $\mathrm{Zn}$ content of different vegetables compared with the values proposed by Singh et al. and Itanna, who suggested that the $\mathrm{Zn}$ contents $(3.56-4.592 \mathrm{mg} / \mathrm{kg})$ were falling in the permissible international standard values $[66,67]$. Contrarily, current results were in close concordance with the results of Al Jassir et al., who found $\mathrm{Zn}$ values between 14.14 and $76.28 \mathrm{mg} / \mathrm{kg}$ in some vegetables.

Sobukola et al., have described $\mathrm{Zn}$ level of $0.011,0.070$ and $0.050 \mathrm{mg} / \mathrm{kg}$ in the aerial parts of different plants [68-71]. The quantities of Zinc in various vegetables observed were less than the permissible levels determined by the FAO/WHO in vegetables [71-73]. Continuous utilization of contaminated vegetables within safe limits may help to protect from the severe consequence of zinc deficiency in human consuming it as Zn deficiency results stunt production and delay in sexual maturity because of its position in organic processes of nucleic acid and formation of different proteins [74]. $\mathrm{Zn}$ is considered as less toxic and important metal for humans as it is essential for regulation of the immunity operations of the body. Low $\mathrm{Zn}$ intake affects more severely as compared to $\mathrm{Zn}$ toxicity.

$\mathrm{Zn}$ is used for supplementation and bio-fortification of staple crops. $\mathrm{Zn}$ proves to be pivotal for cellular activity and catalysis done by biological catalysts. In the arena of metals, $\mathrm{Zn}$ has the lowest noxious effect and critical component of diet as it boosts immunity, protein production and hastens the attenuation of injuries. The mean daily intake of $\mathrm{Zn}$ is $7.00-16.3 \mathrm{mg} \mathrm{Zn}$ per day; but the suggested daily intake $15 \mathrm{mg} \mathrm{Zn}$ per day for males and $12 \mathrm{mg} \mathrm{Zn}$ per day for females. Conversely, its excessive intake may lead to problems such as nausea, kidney unrest and muscular pangs. Analysed $\mathrm{Zn}$ value in coriander was under the limit so it is considered as secure for dietary intake.

\subsection{Bioconcentration factor}

The values of BCF for $\mathrm{Ni}$ and $\mathrm{Zn}$ in samples were given in Table 2. The BCF values of Ni ranged from 0.573 to 0.570 ( $R$. sativus), 0.559 to 0.558 (B. rapa), 0.579 to 0.580 (Z. officinale), 0.637 to 0.635 (C. baccatum), 0.402 to 0.401 ( $C$. frutescens), 0.551 to 0.550 (C. annuum), 0.489 to 0.488 ( $S$. lycopersicum) and 0.542 to 0.539 (C. longa). The highest value of BCF was noticed for $C$. baccatum and the lowest value of BCF was calculated for $C$. frutescens by SWI. Other way around, the BCF values of $\mathrm{Zn}$ differed from $R$. sativus (8.840-8.814), B. rapa (9.555-9.526), Z. officinale (4.210-5.248), C. baccatum (16.528-0-16.478), C. frutescens (4.279-4.264), C. annuum (10.359-10.314), $S$. lycopersicum (8.378-1.142) and $C$. longa (8.105-9.365). The highest BCF values were recorded for $C$. baccatum during CWI and the lowest concentration was present in $C$. frutescens caused by SWI.

Table 2. Bioconcentration factor for vegetable/soil system accumulating nickel and zinc

\begin{tabular}{|l|c|c|c|c|}
\hline \multirow{2}{*}{\multicolumn{1}{|c|}{ Vegetables }} & \multicolumn{2}{c|}{ Nickel } & \multicolumn{2}{c|}{ Zinc } \\
\cline { 2 - 5 } & CWI & SWI & CWI & SWI \\
\hline R. sativus & 0.573 & 0.570 & 8.840 & 8.814 \\
\hline B. rapa & 0.559 & 0.558 & 9.555 & 9.526 \\
\hline Z. officinale & 0.579 & 0.580 & 4.210 & 5.248 \\
\hline C. baccatum & 0.637 & 0.635 & 16.528 & 16.478 \\
\hline C. frutescens & 0.402 & 0.401 & 4.279 & 4.264 \\
\hline C. annuum & 0.551 & 0.550 & 10.359 & 10.314 \\
\hline S. lycopersicum & 0.489 & 0.488 & 8.378 & 1.142 \\
\hline C. longa & 0.542 & 0.539 & 8.105 & 9.365 \\
\hline
\end{tabular}


The value of $\mathrm{BCF}$ less than $1(\mathrm{BCF} \leq 1)$ presents plant only absorption of the metal by the plant body with zero build up. When the value of BCF exceeds 1, it depicts the gathering of metal in plant tissues. The values of $\mathrm{BCF}$ of $\mathrm{Ni}$ was lower than the values of previous studies [75,76]. Iqbal et al., recorded similar values of $\mathrm{BCF}$ for $\mathrm{Ni}$ (0.34-0.93) while comparing with current findings [77]. The value of $\mathrm{BCF}$ for $\mathrm{Zn}$ in current research was higher than the values recorded by Alghobar and suresha [78].

\subsection{Daily intake of metal and health risk index}

DIM values of $\mathrm{Ni}$ and $\mathrm{Zn}$ were given in Table 3. The DIM values recorded for Ni ranged from 0.003 to 0.005 (B. rapa), 0.003 to 0.005 (Z. officinale), 0.003 to 0.005 (R. sativus), 0.003 to 0.006 ( $C$. baccatum), 0.002 to 0.004 ( $S$. lycopersicum), 0.003 to 0.005 (C. annuum), 0.002 to $0.004(C$. frutescens) and 0.002 to 0.005 (C. longa). In collected sample vegetables, DIM values of Ni posed to be higher with SWI than those of CWI. The DIM values for Zn ranged from 0.023 to $0.046(R$. sativus), 0.025 to 0.049 (B. rapa), 0.011 to 0.027 (Z. officinale), 0.043 to 0.085 ( $C$. baccatum), 0.011 to 0.022 (C. frutescens), 0.027 to 0.053 (C. annuum), 0.022 to 0.006 (S. lycopersicum) and 0.021 to 0.048 (C. longa). DIM values for Zn were higher during sewage water irrigation as compared to canal water irrigation in all assessed samples.

The DIM values for $\mathrm{Ni}$ and $\mathrm{Zn}$ found in the current investigation were below tolerable daily intake limitation of $\mathrm{Ni}(1.40 \mathrm{mg} / \mathrm{kg} /$ day) and $\mathrm{Zn}(60 \mathrm{mg} / \mathrm{kg} /$ day). The result showed that HRI of Ni and $\mathrm{Zn}$ were lower than 1 for all vegetables; thus, within the safe limits. In the vegetable samples, the HRI for $\mathrm{Ni}$ and $\mathrm{Zn}$ was greater when irrigated with sewage water and lesser with canal water (Table 3). During current research, HRI of $\mathrm{Ni}$ and $\mathrm{Zn}$ was found to be within the safe range and the vegetables were appraised harmless for humans. The current consequences were in concordance with those of Zhuang et al. [79].

Table 3. Daily intake of metals and health risk index of nickel and zinc contents via intake of different vegetables from canal and sewage wastewater irrigated sites

\begin{tabular}{|c|c|c|c|c|c|c|c|c|}
\hline \multirow{3}{*}{ Vegetables } & \multicolumn{2}{|c|}{ Nickel } & \multicolumn{2}{|c|}{ Zinc } & \multicolumn{2}{|c|}{ Nickel } & \multicolumn{2}{|c|}{ Zinc } \\
\hline & \multicolumn{4}{|c|}{ Daily intake of metal } & \multicolumn{4}{|c|}{ Health risk index } \\
\hline & CWI & SWI & CWI & SWI & CWI & SWI & CWI & SWI \\
\hline R. sativus & 0.003 & 0.005 & 0.023 & 0.046 & 0.15 & 0.25 & 0.0767 & 0.1533 \\
\hline B. rapa & 0.003 & 0.005 & 0.025 & 0.049 & 0.15 & 0.25 & 0.0833 & 0.1633 \\
\hline Z. officinale & 0.003 & 0.005 & 0.011 & 0.027 & 0.15 & 0.25 & 0.0367 & 0.0900 \\
\hline C. baccatum & 0.003 & 0.006 & 0.043 & 0.085 & 0.15 & 0.30 & 0.1433 & 0.2833 \\
\hline C. frutescens & 0.002 & 0.004 & 0.011 & 0.022 & 0.10 & 0.20 & 0.0367 & 0.0733 \\
\hline C. аппиит & 0.003 & 0.005 & 0.027 & 0.053 & 0.15 & 0.25 & 0.0900 & 0.1767 \\
\hline S. lycopersicum & 0.002 & 0.004 & 0.022 & 0.006 & 0.10 & 0.20 & 0.0733 & 0.0200 \\
\hline C. longa & 0.002 & 0.005 & 0.021 & 0.048 & 0.10 & 0.25 & 0.0700 & 0.1600 \\
\hline
\end{tabular}

\subsection{Pollution load index}

PLI values for $\mathrm{Ni}$ and $\mathrm{Zn}$ for the investigated sites were presented in Table 4. The PLI values for Ni in soil samples were 0.0889 and 0.1778 for canal water treatment and sewage wastewater irrigation and for $\mathrm{Zn}$, these values were 0.0101 and 0.0202 . Soil metal contamination can be visualized by PLI, which comparatively assesses the quality of irrigation water. Zero PLI value depicted lowest risk level. 
As the value increases to 1 and above, it shows the gradual collapse of the irrigated soil with such water $[70,81]$.

Table 4. Pollution load index for nickel and zinc in soil

\begin{tabular}{|c|c|c|c|c|}
\hline \multirow{2}{*}{ Sites } & \multicolumn{2}{|c|}{ Nickel } & \multicolumn{2}{c|}{ Zinc } \\
\cline { 2 - 5 } & Reference value & PLI & Reference value & 0.0101 \\
\hline CWI & $9.06^{\mathrm{a}}$ & 0.0889 & $44.19^{\mathrm{a}}$ & 0.0202 \\
\hline
\end{tabular}

Source $^{\mathrm{a}}:[31]$

\section{Conclusions}

Scarcity of fresh water resources forces the agriculturists to use the sewage wastewater to get the maximum output of crops. Wastewater contains huge amounts of micro and macronutrients required for the growth of plants. The results from present work demonstrated that the concentration of Ni and $\mathrm{Zn}$ in the samples were found within the allowable range $(25 \mathrm{mg} / \mathrm{kg}$ and $20 \mathrm{mg} / \mathrm{kg}$, respectively. The bioconcentration factor of $\mathrm{Ni}$ and $\mathrm{Zn}$ in all vegetable samples was lower than 1 . The values of PLI for $\mathrm{Ni}$ and $\mathrm{Zn}$ in both sites were found within the safe limit. The values of HRI for $\mathrm{Ni}$ and $\mathrm{Zn}$ for both canal and sewage water irrigarted sites were les than 1 indicating that the consumtion of these vegtables was safe for human.

Acknowledgements:The authors acknowledge Beijing Vegetable Research Center (Beijing Academy of Agriculture and Forestry Sciences of China) for their scientific support and also Higher Education Commission (HEC), Pakistan for providing the monetary assisstance vide a research project \#2484/13.

\section{References}

1. UGULU, I., Determination of heavy metal accumulation in plant samples by spectrometric techniques in Turkey, Appl. Spectro. Rev., 50(2), 2015, 113-151.

2. QAYYUM S., KHAN I., MENG K., ZHAO Y., PENG C., A review on remediation technologies for heavy metals contaminated soil. Cent. Asian. J. Environ. Sci. Technol. Innov., 1(1), 2020, 21-29.

3. EBADI, A. G., HISORIEV, H., Ecological Assessment of Heavy metals in Sediments of the Farahabad Region (Iran). Polish. J. Environ. Stud., 27(3), 2018, 1033-1039.

4. EBADI, A. G., HISORIEV, H., Metal pollution status of Tajan River-Northern Iran. Toxic. Environ. Chem., 99(9-10), 2017, 1358-1367.

5. EBADI, A. G., TOUGHANI, M., NAJAFI, A., BABAEE, M., A brief overview on current environmental issues in Iran. Cent. Asian. J. Environ. Sci. Technol. Innov., 1(1), 2020, 1-11.

6. DOGAN, Y., BASLAR, S., UGULU, I., A study on detecting heavy metal accumulation through biomonitoring: Content of trace elements in plants at Mount Kazdagi in Turkey, Appl. Ecol. Environ. Res., 12(3), 2014a, 627-636.

7. KHAN, Z. I., UGULU, I., SAHIRA, S., AHMAD, K., ASHFAQ, A., MEHMOOD, N., DOGAN, Y., Determination of Toxic Metals in Fruits of Abelmoschus esculentus Grown in Contaminated Soils with Different Irrigation Sources by Spectroscopic Method, Int. J. Environ. Res., 12, 2018a, 503-511.

8. UNVER, M. C., UGULU, I., DURKAN, N., BASLAR, S., DOGAN, Y., Heavy metal contents of Malva sylvestris sold as edible greens in the local markets of Izmir, Ekoloji, 24(96), 2015, 13-25.

9. UGULU, I., UNVER, M. C., DOGAN, Y., Determination and comparison of heavy metal accumulation level of Ficus carica bark and leaf samples in Artvin, Turkey, Oxid. Commun., 39(1), 2016, 765-775.

10. NNAEMEKA A. N., Environmental pollution and associated health hazards to host communities (Case study: Niger delta region of Nigeria). Cent. Asian. J. Environ. Sci. Technol. Innov., 1(1), 2020, 30-42. 
11. TOUGHANI, M., MANUCHEHRI, H., EBADI, A. G., The effect of salmonidae farms on the changes of the macrobenthos society of the Haraz River from Gazanak to Niyak region (Mazandaran Province of Iran). Cent. Asian. J. Environ. Sci. Technol. Innov., 1(1), 2020, 43-52.

12. MICLEAN, M., LEVEI, E. A., SENILA, M., ROMAN, C., CORDO, E., Assessment of Cu, Pb, Zn and Cd Availability to Vegetable Species Grown in the Vicinity of Tailing Deposits from Baia Mare Area. Rev. Chim., 60(1), 2009, 1-4.

13. PRUTEANU, A., VLADUT, V., CARDEI, P., BORDEAN, D., General Tendencies of the Behaviour of Vegetables Developed in a Soil Contaminated with Heavy Metals. Rev. Chim., 71(2), 2020, 85-90.

14. SAG, Y., KUTSAL, T., Determination of the biosorption activation energies of heavy metals on Zooglea ramigera and Rhizopus arrhizus. Process. Biochem., 35, 2000, 801-807.

15. WANG, H., AN, X., ZHANG, Z., Effect of advanced treatment on ammonia nitrogen contained in secondary effluent from wastewater treatment plant. Fresenius. Environ. Bull., 27(4), 2018, $2043-$ 2050.

16. GU, F., GUO, J., ZHANG, W., SUMMERS, P. A., HALL, P., From waste plastics to industrial raw materials: A life cycle assessment of mechanical plastic recycling practice based on a real-world case study. Sci. Total. Environ., 601, 2017, 1192-1207.

17. GUO, J., ZHANG, X., GU, F., ZHANG, H., FAN, Y., Does air pollution stimulate electric vehicle sales? Empirical evidence from twenty major cities in China. J. Clean. Prod., 249, 2020, 119372.

18. WANG, H., ZHONG, H., BO, G., Existing forms and changes of nitrogen inside of horizontal subsurface constructed wetlands. Environ. Sci. Poll. Res., 25(1), 2018, 771-781.

19. CHEN, X. W., TSZ-FUNG WONG, J., MO, W. Y., MAN, Y. B., WANG-WAI NG, C., WONG, M. H., Ecological Performance of the Restored South East New Territories (SENT) Landfill in Hong Kong (2000-2012), Land. Degrad. Dev., 1, 2012, 1-13.

20. USMAN, A. K., ABDULLAHI, A. H., A OPARA, J., Forest resources management using geospatial tools (Case study: Northern Nigeria). Cent. Asian. J. Environ. Sci. Technol. Innov., 1(1), 2020, 12-20.

21. KAZEMEINI, H. R., RAHIMI, E., KHARRATTAHERDEL, A. A., NOZARPOUR, N., EBADI, A. G., Cadmium concentration in muscle, liver and kidney of sheep slaughtered in Falavarjan abattoir, Iran. Toxic. Indu. Health., 26(5), 2010, 259-263.

22. DOGAN, Y., UNVER, M. C., UGULU, I., CALIS, M., DURKAN, N., Heavy metal accumulation in the bark and leaves of Juglans regia planted in Artvin City, Turkey, Biotechnol. Biotechnol. Equip., 28(4), 2014b, 643-649.

23. NIE, Y., LUO, F., LIN, Q., Dietary nutrition and gut microflora: A promising target for treating diseases. Trends.Food. Sci. Technol., 75, 2018, 72-80.

24. CAUNII1, A., NEGREA, A., PENTEA, M., SAMFIRA, I., MOTOC, M., BUTNARIU, M., Mobility of Heavy Metals from Soil in the Two Species of the Aromatic Plants. Rev. Chim., 66(3), 2015, 382386.

25. DURKAN, N., UGULU, I., UNVER, M. C., DOGAN, Y., BASLAR, S., Concentrations of trace elements aluminum, boron, cobalt and tin in various wild edible mushroom species from Buyuk Menderes River Basin of Turkey by ICP-OES, Trace. Elem. Electroly., 28(4), 2011, 242-248.

26. CHIBUIKE, G. U., OBIORA, S. C., Heavy Metal Polluted Soils: Effect on plants and bioremediation methods, Appl. Environ. Soil. Sci., 1, 2014, 1-13.

27. JABEEN, S., MAHMOOD, Q., NAWAB, B., High economic impacts of poor water and sanitation in various communities in Pakistan (An environmental economic perspective). Cent. Asian. J. Environ. Sci. Technol. Innov., 1(1), 2020, 53-60.

28. NWANKWOALA, H. O., OMOFUOPHU, E., Investigation of hydrocarbon contaminant levels and groundwater quality assessment in parts of bonny island, rivers state of Nigeria. Cent. Asian. J. Environ. Sci. Technol. Innov., 1(1), 2020, 61-70.

29. ALEAGHA, M. M., EBADI, A. G., Study of heavy metals bioaccumulation in the process of vermicomposting. Afr. J. Biotechnol., 10(36), 2011, 6997-7001. 
30. DOGAN, Y., UGULU, I., BASLAR, S., Turkish red pine as a biomonitor: a comparative study of the accumulation of trace elements in needles and barks, Ekoloji, 19(75), 2010, 88-96.

31. UGULU, I., DOGAN, Y., BASLAR, S., VAROL, O., Biomonitoring of trace element accumulation in plants growing at Murat Mountain, Int. J. Environ. Sci. Tech., 9, 2012, 527-534.

32. EBADI, A. G., HISORIEV, H., The prevalence of heavy metals in Cladophora glomerata L. from Farahabad Region of Caspian Sea-Iran. Toxic. Environ. Chem., 99(5-6), 2017, 883-891.

33. CAUNII1, A., NEGREA, A., PENTEA, M., SAMFIRA, I., MOTOC, M., BUTNARIU, M., Mobility of Heavy Metals from Soil in the Two Species of the Aromatic Plants. Rev. Chim., 66(3), 2015, 382386.

34. JORDAO C. P., NASCENTES, C. C., CECON, P. R., FONTES, R. L. F., PEREIRA, J. L., Heavy metal availability in soil amended with composted urban solid wastes, Environ. Monitor. Assess., 112, 2006, 309-326.

35. NADEEM, M., QURESHI, T. M., UGULU, I., RIAZ, M. N., AN, Q. U., KHAN, Z. I., AHMAD, K., ASHFAQ, A., BASHIR, H., DOGAN, Y., Mineral, vitamin and phenolic contents and sugar profiles of some prominent date palm (Phoenix dactylifera) varieties of Pakistan, Pak. J. Bot., 51(1), 2019, 171-178.

36. LEI, Z., YANG, J., HUIBIN, H., CHAO, Y., MIN, L., LINTIAN, M., Preparation of soybean oil factory sludge catalyst by plasma and the kinetics of selective catalytic oxidation denitrification reaction. J. Clean. Prod., 217, 2019, 317-323.

37. LEI, Z., JIHAO, C., ZHANG, L., HUIBIN, H., YUSU, W., YONGHUI, L., Preparation of soybean oil factory sludge catalyst and its application in selective catalytic oxidation denitration process. J. Clean. Prod., 225, 2019, 220-226.

38. AHMAD, K., NAWAZ, K., KHAN, Z. I., Effect of diverse regimes of irrigation on metals accumulation in wheat crop: An assessment-dire need of the day, Fresenius. Environ. Bull., 27(2), 2018, 846-855.

39. GAO, W., WANG, Y., WANG, W., SHI, L., The first multiplication atom-bond connectivity index of molecular structures in drugs. Saudi Pharmaceutical Journal, 25(4), 2017, 548-555.

40. GAO, W., WANG, Y., BASAVANAGOUD, B., JAMIL, M. K., Characteristics studies of molecular structures in drugs. Saudi. Pharm. J., 25(4), 2017, 580-586.

41. KHAN, Z. I., UGULU, I., UMAR, S., AHMAD, K., MEHMOOD, N., ASHFAQ, A., BASHIR, H., SOHAIL, M., Potential toxic metal accumulation in soil, forage and blood plasma of buffaloes sampled from Jhang, Pakistan, Bull. Environ. Contam. Toxicol., 101, 2018b, 235-242.

42. AL JASSIR, M. S., SHAKER, A., KHALIQ, M. A., Deposition of heavy metals on green leafy vegetables sold on roadsides of Riyadh city, Saudi Arabia, Bull. Environ. Contam. Toxicol., 75, 2005, 1020-1027.

43. JARUP, L., Hazards of heavy metal contamination. Br. Med. Bull., 68, 2003, 167-182.

44. KHAN, Z. I., UGULU, I., AHMAD, K., YASMEEN, S., NOORKA, I. R., MEHMOOD, N., SHER, M., Assessment of Trace Metal and Metalloid Accumulation and Human Health Risk from Vegetables Consumption through Spinach and Coriander Specimens Irrigated with Wastewater, Bull. Environ. Contam. Toxicol., 101(6), 2018c, 787-795.

45. CAO, L., TU, C., HU, P., LIU, S., Influence of solid particle erosion (SPE) on safety and economy of steam turbines. Appl. Therm. Eng., 150, 2019, 552-563.

46. LEI, Z., GAO, H., CHANG, X., ZHANG, L., WEN, X., WANG, Y., An application of green surfactant synergistically metal supported cordierite catalyst in denitration of Selective Catalytic Oxidation. J. Clean. Prod., 249, 2020, 119307.

47. ZHU, B., ZHOU, X., LIU, X., WANG, H., HE, K., WANG, P., Exploring the risk spillover effects among China's pilot carbon markets: A regular vine copula-CoES approach. J. Clean. Prod., 242, $2020,118455$.

48. ZHU, B., SU, B., LI, Y., Input-output and structural decomposition analysis of India's carbon emissions and intensity, 2007/08-2013/14. Appl. Energ., 230, 2018, 1545-1556. 
49. ZHANG, T., WU, X., SHAHEEN, S. M., ZHAO, Q., LIU, X., RINKLEBE, J., REN, H., Ammonium nitrogen recovery from digestate by hydrothermal pretreatment followed by activated hydrochar sorption. Chem. Engine. J., 379, 2020, 122254.

50. WAJID, K., AHMAD, K., KHAN, Z. I., NADEEM, M., BASHIR, H., CHEN, F., UGULU, I., Effect of organic manure and mineral fertilizers on bioaccumulation and translocation of trace metals in maize, Bull. Environ. Contam. Toxicol., 2020. https://doi.org/10.1007/s00128-020-02841-w.

51. SAJJAD, K., FAROOQ, R., SHAHBAZ, S., KHAN, M. A., SADİUE, M., Health risk assessment of heavy metals for population via consumption of vegetables, World. Appl. Sci. J., 6, 2009, 1602-1606.

52. CUİ, Y. J., ZHU, Y. G., ZHAİ, R. H., CHEN, D. Y., HUANG, Y. Z., QUİ, Y., LİANG, J. Z., Transfer of metals from near a smelter in Nanning, China, Environ. Int., 30, 2004, 785-791.

53. CUI, Y. L., ZHU, R. H., ZHI, R. H., CHEN, D. Y., HUANG, Y.Z., QIU, Y., Transfer of metals from soils to vegetables in an area near a smelter in Nanning, China, Environ. Int., 30, 2004, 785-791.

54. ROWELL, D.L. 1994. Soil Science method and applications: Pesticides and Metals. Longman Singapore Publisher (Ptc) Ltd. Singapore. pp.303- 327.

55. CHIROMA, T. M., EBEWELE, R. O., HYMORE F. K., Comparative assessment of heavy metal levels in soil, vegetables and urban grey wastewater used for irrigation in Yola and Kano, Int. Ref. $J$. Eng. Sci., 3, 2014, 1-9

56. ORİSAKWE, O. E., NDUKA, J. K., AMADİ, C. N., DİKE, D. O., BEDE, O., Heavy metals health risk assessment for population via consumption of food crops and fruits in Owerri, South Eastern, Nigeria, Chem. Cent. J., 6(1), 2012, 77.

57. CEMPEL, M., NIKEL, G., Nickel: A review of its sources and environmental toxicology, Polish. J. Environ. Stud., 15, 2006, 375-382.

58. WANG, M., ZHANG, D., CHENG, Y., TAN, S. K., Assessing performance of porous pavements and bioretention cells for stormwater management in response to probable climatic changes. J. Environ. Manage., 243, 2019, 157-167.

59. LYNCH, E., BRAITHWAİTE, R., A review of the clinical and toxicological aspects of 'traditional'(herbal) medicines adulterated with heavy metals, Expert. Opin. Drug. Saf., 4(4), 2005, 769-778.

60. KABATA-PENDİAS, A., MUKHERJEE, A. B., Trace elements of group 12 (Previously group IIb), Trace. Elem. Soil. Human., 12, 2007, 283-319.

61. GUO, J., PAN, J., GUO, J., GU, F., KUUSISTO, J., Measurement framework for assessing disruptive innovations. Technol. Forecast. Soc. Change., 139, 2019, 250-265.

62. ZENG, L., CHEN, G., CHEN, H., Comparative Study on Flow-Accelerated Corrosion and ErosionCorrosion at a $90^{\circ}$ Carbon Steel Bend. Materials, 13(7), 2020, 1780-1796.

63. WANG, H., WANG, J., LU, H., BO, G., ZHANG, X., CAO, Y., LIU, L., ZHANG, J., ZHANG, W., Analysis of coating electrode characteristics in the process of removing pollutants from wastewater. Fresenius. Environ. Bull., 29(2), 2020, 715-721.

64. GU, F., ZHANG, W., GUO, J., HALL, P., Exploring “Internet+ Recycling": Mass balance and life cycle assessment of a waste management system associated with a mobile application. Sci. Total. Environ., 649, 2019, 172-185.

65. CHEN, S., HASSANZADEH-AGHDAM, M. K., ANSARI, R., An analytical model for elastic modulus calculation of $\mathrm{SiC}$ whisker-reinforced hybrid metal matrix nanocomposite containing $\mathrm{SiC}$ nanoparticles. J. Alloys. Compd., 767, 2018, 632-641.

66. SINGH, A., SHARMA, R. K., AGRAWAL, M., MARSHALL, F. M., Health risk assessment of heavy metals via dietary intake of food stuffs from the wastewater irrigated site of a dry tropical area of India, Food. Chem. Toxicol., 48(2), 2010, 611-619.

67. ITANNA, F., Metals in leafy vegetables grown in Addis Ababa and toxicology implications, Ethiop. J. Health. Dev., 16, 2002, 295-302. 
68. SOBUKOLA, O. P., ADENIRAN, O. M., ODEDAIRO, A. A., KAJIHAUSA O. E., Heavy metal levels of some fruits and leafy vegetables from selected markets' in Lagos, Nigeria December, Afr. $J$. Food. Sci., 4(2), 2010, 389-393.

69. HAIBIN, L., ZHENLING, L., Recycling utilization patterns of coal mining waste in China. Resour. Conserv. Recycl., 54(12), 2010, 1331-1340.

70. QUAN, Q., HAO, Z., XIFENG, H., JINGCHUN, L., Research on water temperature prediction based on improved support vector regression. Neur. Comp. App., 2020, 1-10.

71. CAO, Y., WANG, Q., FAN, Q., NOJAVAN, S., JERMSITTIPARSERT, K., Risk-constrained stochastic power procurement of storage-based large electricity consumer. J. Energy. Stor., 28, 2020, 101183-101192.

72. CAO, Y., LI, Y., ZHANG, G., JERMSITTIPARSERT, K., NASSERI, M., An efficient terminal voltage control for PEMFC based on an improved version of whale optimization algorithm. Energy Reports, 6, 2020, 530-542.

73. WANG, P., LI, J. B., BAI, F. W., LIU, D. Y., XU, C., ZHAO, L., WANG, Z. F., Experimental and theoretical evaluation on the thermal performance of a windowed volumetric solar receiver. Energy, 119, 2017, 652-661.

74. Barminas J. T. Charles, M., Emmanuel, D., Mineral Composition of Non conventional Leafy Vegetables, Plant. Food. Hum. Nut., 53, 1998, 29-36.

75. KHAN, S., REHMAN, S., KHAN, A. Z., KHAN, M. A., SHAH, M. T., Soil and vegetables enrichment with heavy metals from geological sourves in Gilgit, northern Pakistan, Ecotoxicol. Environ. Saf., 73(7), 2010, 1820-1827.

76. MAHMOOD, A., MALIK, R. N., Human health risk assessment of heavy metals via consumtion of contaminated vegetables collected from different irrigation sources in Lahore, Pakistan, Arab. J. Chem., 7(1), 2014, 91-99

77. IQBAL, H. H., TASEER, R., ANWAR, S., MUMTAZ, M., QADIR, A., SHAHID, N., Human health risk assessment: Heavy metal contamination of vegetables in Bahawalpur, Pakistan, Bull. Environ. Stud., 1(1), 2016, 10-17.

78. ALGHOBAR, M. A., SURESHA, S., Evaluation of nutrients and trace metals and their enrichment factors in soil and sugarcane crop irrigated with wastewater, J. Geosci. Environ. Prot., 3, 2015, 46-56.

79. ZHUANG, P., MCBRIDE, M. B., XİA, H., Lİ, N., Lİ, Z., Health risk from heavy metals via consumption of food crops in the vicinity of Dabaoshan mine, South China, Sci. Total. Environ., 407(5), 2009, 1551-156.

80. ANGUlO, E., The Tomlinson Pollution Load Index applied to heavy metal, 'Mussel-Watch'data: a useful index to assess coastal pollution, Sci. Total. Environ., 187(1), 1996, 19-56.

81. TOMLINSON, D. L., WILSON, J. G., HARRIS, C. R., JEFFREY, D. W., Problems in the assessment of heavy metal levels in estuaries and the formation of a pollution index, Helgol. Meeresunt., 33, 1980, $566-575$.

$\overline{\text { Manuscript received: } 7.04 .2020}$ 